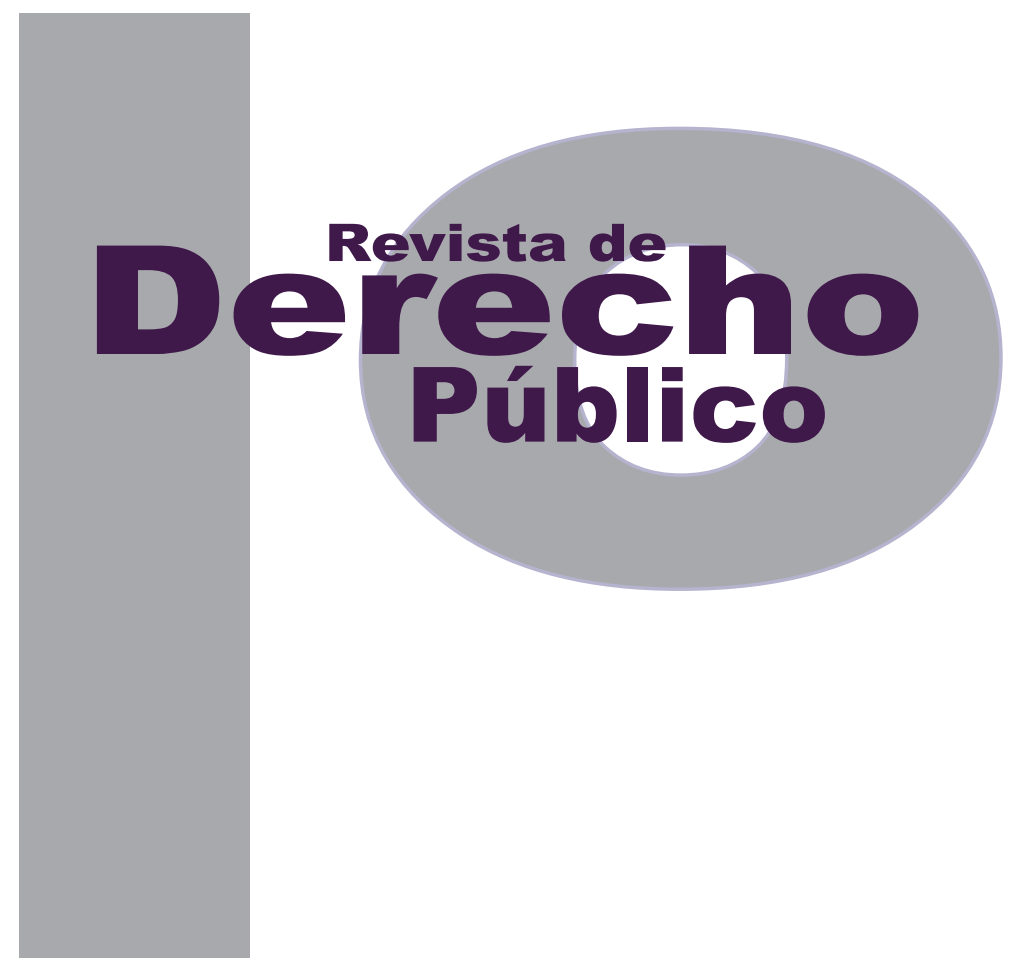

\title{
LA HUIDA DEL DERECHO ADMINISTRATIVO EN ESPAÑA Y EN COLOMBIA. UN PANORAMA DESDE LAS ENTIDADES DESCENTRALIZADAS
}

\author{
DAVID ANDRÉS SERRANo SALOMÓN
}

Artículo corto

DOI: http://dx.doi.org/10.15425/redepub.34.2015.07

Universidad de los Andes

Facultad de Derecho

Revista de Derecho Público N. ${ }^{\circ} 34$

Enero - Junio de 2015. ISSN 1909-7778 


\title{
La huida del derecho administrativo en España y en Colombia. Un panorama desde las entidades descentralizadas
}

\section{Resumen}

La aplicación de principios y reglas de derecho privado a la actividad y organización de la administración pública es un acontecer que ha permeado a distintos sistemas jurídicos en virtud de la asunción y reformulación de ciertos fines y modelos de gestión del Estado. Sin embargo, se podría decir que la huida del derecho administrativo es un fenómeno que, por antonomasia, es propio del derecho español tanto por la intensidad que este llegó a alcanzar como por su correlativo impacto en la doctrina administrativista. Esa es la razón por la que el presente escrito indaga sobre sus antecedentes jurídicos, motivaciones y posturas doctrinales.

A partir de ello, se contrasta el fenómeno de la huida con las particularidades del ordenamiento jurídico colombiano. De este modo, se sostendrá que a pesar de que Colombia no ha estado exenta de remisiones al derecho privado, en todo caso esta no ha tenido la misma profundidad y vigor que la del derecho español. Lo anterior, en atención tanto a la misma dinámica de nuestra administración descentralizada como por las divergencias doctrinales de nuestro país.

Palabras clave: huida del derecho administrativo, derecho administrativo, administración pública, función administrativa, administración institucional, entidades descentralizadas, derecho privado.

\section{The escape of administrative law in Spain and Colombia. An overview from the decentralized entities}

\begin{abstract}
The application of principles and rules of private law to the activity and organization of the public administration is an event that has permeated various legal systems by virtue of the assumption and reformulation of certain purposes and models of the state management. However, one could say that the "escaping of administrative law" phenomenon par excellence, belongs to the Spanish law because of the intensity it had reached, as well as its correlative impact on the administrative doctrine. This is the reason why this abstract investigates its legal background, motivations and doctrinal positions.

From here on, there is a contrast between the phenomenon of the escaping with the peculiarities of the Colombian legal system. Thus, they argue that although Colombia has not been exempt of remissions to private law, in any case, it has not had the same depth and force as the Spanish law. Thus, on account of the same dynamic of our decentralized administration as for the doctrinal differences of our country.

Keywords: escaping of administrative law, administrative law, public administration, administrative function, institutional administration, decentralized entities, private law.

\section{A fuga do direito administrativo na Espanha e na Colômbia. Um panorama desde as entidades descentralizadas}

\section{Resumo}

A aplicação de princípios e regras de direito privado à atividade e organização da administração pública é um acontecer que tem permeado a distintos sistemas jurídicos, em virtude da assunção e reformulação de certos fins e modelos de gestão do Estado. Porém, se poderia dizer que a fuga do direito administrativo é um fenômeno que, por antonomásia, é próprio do direito espanhol tanto pela intensidade que este chegou a alcançar quanto por seu correlativo impacto na doutrina administrativista. Essa é a razão pela que o presente escrito indaga sobre sus antecedentes jurídicos, motivações e posturas doutrinais.

A partir disso, se contrasta o fenômeno da fuga com as particularidades do ordenamento jurídico colombiano. Deste modo, se sustentará que apesar de que a Colômbia não tem estado isenta de remissões ao direito privado, em todo caso esta não tem tido a mesma profundidade e vigor que a do direito espanhol. 0 anterior, em atenção tanto à mesma dinâmica de nossa administração descentralizada quanto pelas divergências doutrinais de nosso país.

Palavras-chave: fuga do direito administrativo, direito administrativo, administração pública, função administrativa, administração institucional, entidades descentralizadas, direito privado 


\title{
La huida del derecho administrativo en España y en Colombia. Un panorama desde las entidades descentralizadas*
}

\author{
David Andrés Serrano Salomón ${ }^{* *}$
}

\section{SUMARIO}

Introducción - I. DE LA HUIDA DEL DERECHO ADMINISTRATIVO EN ESPAÑA- A. Aspectos generales y alcance conceptual de la huida del derecho administrativo - B. Antecedentes y motivos jurídicos de la huida del derecho administrativo - C. Posiciones doctrinales en relación con la huida del derecho administrativo - II. DE LA HUIDA DEL DERECHO ADMINISTRATIVO EN COLOMBIA - A. Aspectos previos - 1. De la huida hacia el derecho privado en el ordenamiento jurídico colombiano. Alcances y consecuencias - 1.1. Simetría entre forma, régimen jurídico y contenido - 1.2. Dosificaciones de la Corte Constitucional. Asociación entre entidades públicas - 1.3. Transformación constitucional de la naturaleza jurídica de los servicios públicos. Cambio de paradigma - 1.4. La remisión al derecho privado no es absoluta - 1.5. Limitaciones constitucionales - 2. Posturas doctrinales de la huida del derecho administrativo en Colombia - III. CONCLUSIONES - Referencias.

* Cómo citar este artículo: Serrano Salomón, D. A. (Junio, 2015). La huida del derecho administrativo en España y en Colombia. Un panorama desde las entidades descentralizadas. Revista de Derecho Público, 34. Universidad de los Andes (Colombia).

** Abogado de la Universidad de San Buenaventura de Cali. Especialista en derecho administrativo de la Universidad Pontificia Bolivariana de Medellín. Abogado externo de las Empresas Municipales de Cali EMCALI EICE-ESP. Correo: davidss89@hotmail.com. 
Introducción

El fenómeno conocido como huida del derecho administrativo es un acontecer jurídico positivo, advertido y denunciado por la doctrina española en las dos últimas décadas del siglo pasado. La literatura sobre el particular es prolija. Es un tema recurrente de la doctrina administrativista del país ibérico.

El debate en torno a dicho tópico ha venido de la mano del derecho positivo español, y, en especial, en virtud de su administración institucional. Han sido, ciertamente, las disposiciones jurídicas singulares introducidas a ciertas entidades de derecho público del aludido país, como las reformas orgánicas de carácter general que se adoptaron en razón de las leyes relativas a los presupuestos generales del Estado, las que dieron pie a la materialización de dicho fenómeno. De allí que no sea gratis que, en su momento, a las aludidas transformaciones jurídicas se las haya denominado la "nueva descentralización funcional privatizadora" (Garrido, 1991, pág. 20).

De acuerdo con lo anterior, el presente texto busca, en primer lugar, decantar sintéticamente cuál ha sido el alcance que la doctrina española le ha otorgado al fenómeno conocido como huida del derecho administrativo, así como describir los motivos jurídicos que han dado lugar a dicho debate. Motivos que, se adelanta, están asociados con la administración descentralizada, indirecta, institucional o instrumental del Estado. Por ello será menester en el presente escrito dar una ojeada, desde la dogmática jurí- dico-administrativa, sobre el significado que han representado dichas entidades.

En atención a lo precedente, y como segundo punto, este trabajo tiene como objetivo estudiar cuál ha sido la receptividad que ha tenido dicho tema en el sistema jurídico colombiano. Es decir, si el fenómeno de la huida se ha transpolado en nuestro ordenamiento, lo cual demanda la revisión somera de nuestras entidades descentralizadas así como de las posturas doctrinales de los juristas administrativistas de nuestro país.

Por último, y como tercer aparte del presente artículo, a modo de conclusión se intenta dar una visión personal de lo que este fenómeno ha representado en nuestro ordenamiento jurídico con base en el estudio anterior.

\section{DE LA HUIDA DEL DERECHO ADMINISTRATIVO EN ESPAÑA}

\section{A. Aspectos generales y alcance conceptual de la huida del derecho administrativo}

Como aproximación inicial al tema, vale decir que la misma denominación conocida como huida del derecho administrativo es equívoca, pues, en efecto, las primeras cuestiones que uno puede advertir son de qué fenómeno específico se huye, hacia dónde se huye y de qué tipo de derecho administrativo esa situación jurídica específica se está sustrayendo.

Existen, sobre el particular, otros apelativos sobre el mismo tema que ayudan, de cierto modo, 
a dar una idea de los alcances de dicho tópico. Así, también a la huida del derecho administrativo se le designa como huida hacia el derecho privado, o huida de la administración hacia el derecho privado.

De las anteriores acepciones se advierte claramente que la evasión del derecho administrativo es hacia el derecho común. Esta distinción supone, entonces, reconocer una cierta dicotomía entre el derecho público (administrativo) y el derecho privado, la cual da lugar al reconocimiento de que los dos términos se condicionan mutuamente en cuanto se reclaman uno a otro (Bobbio, 1989, págs. 11-12).

Con todo, una de las mayores dificultades consiste en dilucidar cuál es el objeto y de qué tipo de derecho administrativo se está hablando, dado que es a dicho subsistema jurídico normativo al que precisamente se le evade. Al respecto, no se puede soslayar que dicha disciplina jurídica se caracteriza por su movilidad, su dinamismo, ya que el "objeto del derecho administrativo no solo se centra en la pura y simple administración y realidad social, sino también en la teoría misma del Estado, que de por sí implica transformaciones permanentes en razón de su contenido político" (Santofimio, 2001, pág. 175). De allí que el contenido y alcance de las categorías administrativistas que instrumentan una época sean inservibles o no tengan la misma preponderancia en otra, pues estas se modulan al compás de la demandas de la sociedad y la estructura política. ${ }^{1}$

Piénsese, por ejemplo, en el desplazamiento de la actividad de policía administrativa por parte de la actividad de regulación ante las nuevas
Conscientes de que el problema del objeto del derecho administrativo es de por sí complejo, máxime cuando no existe unanimidad en la doctrina, podemos decir que su fuente de estudio es la administración pública en un sentido dual, esto es, como categoría tanto material como subjetiva. En el primer sentido, administración equivale a actividad, acción o función administrativa; en el segundo sentido corresponde a estructura orgánica, que en algunas ocasiones coincide con los órganos que hacen parte de la rama ejecutiva y, en otras, la trasciende; ello depende, en suma, de cada sistema jurídico. Las diferencias doctrinales al respecto, descansan, en últimas, en el predominio que se le dé a uno u otro sentido.

Como caracterización del derecho administrativo, y desde una aproximación conceptual francesa podemos decir que este subsistema jurídico sobresale por contener un cuadro de principios y reglas derogatorias del derecho común. De esta manera, en la terminología de Jean Rivero (2002), la administración aparece como un poder superior al de los particulares ("derogaciones en más"), pero, del mismo modo, sujeta a una serie de reglas que la hacen menos libre en el ejercicio de su voluntad que las relaciones interprivatos ("derogatorias en menos").

Esta diferenciación es importante, toda vez que la denuncia de la doctrina española en relación

contingencias de seguridad producto de los riesgos generados por la sociedad postindustrial. Para tal efecto, puede verse Esteve Pardo, J. (Enero-diciembre, 2014). Perspectiva e impacto de la crisis desde la nueva correlación entre Estado y sociedad. Revista da Nueva Época, (1). Obtenido de: http://revistasonline.inap.es/index.php?journal=DA\& page=article\&op=view\&path $\% 5 B \% 5 D=10168 "$ 
con la renuncia de la administración pública al derecho administrativo consiste, precisamente, en que la utilización del derecho privado ha dado lugar a que se burlen los principios de objetividad, transparencia y libre concurrencia en materia de contratación; a la disposición libre de sus bienes; y a la vinculación discrecional de su funcionariado; aspectos que no podrían darse de haberse observado el cuadro de derogatorias en menos que informa el derecho público.

Llegados a este punto, se puede decir entonces que el objeto del derecho administrativo es la administración pública en sentido material y subjetivo; que tal derecho se caracteriza por contener un conjunto de prerrogativas y privilegios, pero de igual manera, una serie de garantías y limitaciones que no le permiten actuar libremente; y que la huida va dirigida hacia la instrumentación de las técnicas y formas del derecho privado. Solo queda por precisar a qué fenómeno o situación jurídica en particular es la que se evade. En otros términos, establecer “cuáles son los campos de regulación que sólo pertenecen al derecho administrativo, si es que los hay; y hasta qué punto la aplicación del derecho privado a la Administración pública constituye realmente una huida de esta del derecho administrativo" (Brewer-Carías, 2005, pág. 217).

Pues bien, sea lo primero decir que para la doctrina del país ibérico el derecho administrativo es el subsistema jurídico que le es propio y específico a la administración (García de Enterría y Fernández, 2006). ${ }^{2}$ Sin embargo, la presencia

2 El "derecho administrativo es el Derecho propio y específico de las Administraciones públicas en cuanto sujetos. Tiene carácter estatu- del derecho privado en el seno de la administración ha sido una constante en su devenir; más aún, se remonta al origen mismo de la ciencia jurídico-administrativa y se ha servido de ella con toda normalidad (Descalzo González, 2011, pág. 41). De ahí que se diga que el derecho administrativo no es un derecho exclusivo y excluyente de otras ramas que le puedan ser aplicables. Es perfectamente común y posible que en el quehacer de la administración pública exista una suerte de interaplicación del derecho administrativo y el privado, o, incluso, que dentro de un mismo acto existan elementos que estén sometidos a estos dos subsistemas jurídicos normativos (Brewer-Carías, 2005, pág. 217).

Así entonces, para efectos de precisar cuál es el campo que reclama el derecho administrativo como suyo, es de señalar que la doctrina ha hecho intentos a lo largo del tiempo por formular criterios que tengan la virtualidad de determinar cuándo ha de aplicarse este y cuándo otras ramas del derecho. De esta suerte, por ejemplo, dan cuenta del criterio de la distinción entre actos de autoridad y actos de gestión; el criterio del servicio público; el criterio del fin perseguido por la actividad administrativa; y el criterio de la prerrogativa -que constituye una revalorización del primer criterio- (Garrido, 1985, págs. 171-

\footnotetext{
tario y constituye para sus singulares sujetos un verdadero Derecho común, capaz de autointegrar sus propias lagunas sin necesidad de acudir a otros ordenamientos diferentes" (pág. 64). Con todo, no toda la doctrina española comparte la visión estatutaria del derecho administrativo. Así, para autores como Esteve Pardo (2012), en virtud de la nueva dinámica alcanzada por el Estado-sociedad, es claro que la perspectiva estatutaria se halla superada toda vez que hoy día el derecho público administrativo es aplicable a los particulares en tanto que el "garantismo de nuevo cuño se endereza ahora a garantizar la extensión y tutela de los intereses generales frente a sujetos privados que ostentan situaciones de poder por ejercer funciones públicas $u$ operar como prestadores de servicios de interés general" (pág. 21).
} 
202). De este modo, se apunta que el derecho administrativo será aplicable cuando la administración actúa con poder o autoridad, cuando gestiona actividades de carácter prestacional, cuando su actividad tenga por objeto la búsqueda del interés público, o cuando hace uso de privilegios o prerrogativas exorbitantes.

Estos criterios, si se repara con atención, no son más que algunos de los razonamientos por medio de los cuales se ha querido edificar la síntesis de la función administrativa. Por ello es que autores como García de Enterría y Fernández (2006) aseguran, en un sentido más general, que el derecho administrativo es aplicable en aquellos casos en que la administración pública realiza una "función típica", es decir, una actividad "propiamente administrativa” (pág. 60). Si ello es así, claramente se entiende, siguiendo a la doctrina española, que la huida del derecho administrativo se configura cuando a las actividades auténticamente administrativas se aplican los procedimientos, las formas y las técnicas del derecho privado (Martín-Retortillo, 1996).

Este es el punto que conviene retener. La instrumentación del derecho común a aquellas funciones materialmente administrativas por parte de la administración pública es la que, en suma, reprocha la doctrina española, y lo que comporta, en estricto sentido, la huida del derecho administrativo, que no es más que la disociación entre función administrativa y derecho administrativo. ${ }^{3}$

Desde luego, las dificultades no se agotan allí. El problema subsiguiente radica en entrever en qué casos concretos existe o no función administrativa. Téngase en cuenta que la función administrativa es un
Por ello, a modo de conclusión se puede decir que no debe entenderse como comprensivo de dicho fenómeno las siguientes situaciones: i) cuando ciertas funciones, actividades y servicios que eran prestados por entidades estatales son asignados o compartidos con particulares, dado que se trata simplemente de una manifestación de la llamada descentralización por colaboración, en la que los particulares desarrollan funciones públicas a través de los cauces del derecho público; ii) cuando entidades de propiedad exclusiva del Estado pasan total o parcialmente a ser propiedad de particulares, pues estamos ante una privatización institucional, que da lugar al retraimiento del Estado de aquellas tareas que, en otrora, las gestionaba directamente; y, sobre todo, iii) cuando se adoptan formas jurídicas de derecho común -entiéndase sociedades mercantiles- por parte de la administración o la aplicación del derecho privado a organismos institucionalmente definidos como entidades públicas, pero para desarrollar funciones relativas a la producción y dación de bienes al mercado en un régimen de competencia, ya que en tal caso se trata de la asunción de fines y tareas por parte del Estado que, de ordinario, han sido propias de los particulares.

\section{B. Antecedentes y motivos jurídicos de la huida del derecho administrativo}

Comoquiera que los orígenes de la huida del derecho administrativo surgen en el marco de la administración institucional o funcional del Es-

concepto jurídico indeterminado cuya precisión en abstracto es complejo dilucidar. 
tado, también llamados en España en un sentido genérico organismos autónomos, conviene precisar, así sea sintéticamente, lo que para la dogmática jurídico-administrativa ${ }^{4}$ ha significado este tipo de entidades, para luego concretarlo con el objeto del presente estudio.

Al respecto, lo primero que se puede decir, y como ya es de suyo conocido, es que este tipo de entidades constituyen una técnica del Estado por medio de la cual la administración directa personifica jurídicamente ciertas actividades, funciones o intereses que se entienden como parte de su resorte. Por ello, a estos órganos estatales se los consideran "meras organizaciones instrumentales diferenciadas y dependientes de la administración de la que están adscritas" (Entrena Cuesta, 1998, pág. 25). De este modo, nacen entidades que, aunque hacen parte de los cuadros de la administración pública, se aíslan relativamente de la administración central amén de su personería jurídica para gestionar más ágilmente ciertos intereses que no son otros que los del mismo Estado.

La expansión de la administración institucional es producto de una lógica distinta entre Estadosociedad de la que se presentaba en el Estado decimonónico. En este, ciertamente, con ocasión del dogma liberal, existía una estricta separación entre Estado y sociedad bajo la égida

Se hace hincapié en este aspecto, esto es, en la dogmática jurídicoadministrativista, porque el presente escrito no pretende dilucidar las motivaciones políticas que estuvieron detrás del nacimiento de la administración institucional. Motivaciones que dependen en todo caso de las circunstancias especiales y la realidad política de cada país. Para una visión desde esa perspectiva puede verse: Ariño Ortiz, G. (Septiembre-diciembre, 1970). La Administración Institucional: origen y personalidad. Revista de Administración Pública, (63), 85-130. de que el primero era un mal necesario (Bobbio, 2010, pág. 22), y que, en tal virtud, sus funciones se limitaban al mantenimiento del orden público; por el contrario, era en el seno de la sociedad civil donde se desenvolvían los individuos en su esfera moral y económica. Por tal razón es que la estructura orgánica de la administración pública de entonces era angosta y centralizada, animada al ejercicio de funciones policivas con el fin de garantizar el desarrollo de las libertades individuales dentro de un marco de legalidad estricto (Montaña, 2010, pág. 78).

En contraste con lo anterior, entrado el siglo XX, el modelo de Estado social se instala para intervenir ampliamente sobre la sociedad en cumplimiento de los mandatos que pregonan los derechos sociales y la actividad prestacional que imponen las constituciones en el tramo central de dicho siglo, postulando, de esta suerte, una constante y difusa interrelación, una supuesta integración entre Estado y sociedad (Esteve Pardo, 2012, pág. 13). Ese nuevo haz de responsabilidades materiales en cabeza de la administración requería de ella un ensanchamiento de su estructura orgánica. La imposibilidad fáctica de atender desde el nivel central todos los asuntos que le conciernen al Estado, aunada a la complejidad y heterogeneidad de sus cometidos que exigen una mayor tecnificación de los organismos y entidades que componen la administración pública, dio lugar a su transformación a través de la creación de nuevas fórmulas organizativas tanto para la provisión de bienes y servicios públicos como para la prestación eficiente de funciones administrativas altamente especializadas. Bajo ese contexto es 
que se da una expansión de la administración institucional. ${ }^{5}$

Es, pues, bajo esa lógica también que la administración institucional o la descentralización por servicios debía responder, por lo menos en teoría, al modelo weberiano, el cual procuraba la tecnificación y profesionalización en la prestación de servicios al margen de las presiones coyunturales de la política (Medina, 2007). Por tal virtud, verbigracia, en Francia, en razón de la nueva descentralización, se buscaba conseguir a través de los establecimientos públicos o de los servicios públicos personificados aislar dichas actividades del abrigo "de las luchas políticas que los partidos ventilaban en el seno de la administración centralizada, asegurando con ello una independencia de juicio y decisión" (Tafur, 1977, pág. 17).

Empero, lo que resulta más relevante para los efectos del presente escrito, es que la administración descentralizada, a fin de materializar los propósitos para los cuales fue concebida, demandaba una huida del derecho general de la administración, toda vez que este resultaba excesivamente rígido y limitante para las nuevas tareas del Estado. Se quería conseguir, por lo pronto, “una mayor libertad de acción, una necesaria flexibilidad en su regulación, porque la prestación de algunos servicios públicos no puede hacerse eficazmente de acuerdo con los

5 En las últimas tres décadas se puede hablar nuevamente de un retraimiento de la administración institucional del Estado en virtud de fenómenos de privatización y liberalización de ciertas actividades producto de lo que se ha denominado la crisis del Estado social. En contraste, se adopta una nueva institucionalidad bajo la entronización de entidades y agencias independientes (modelo norteamericano) como corolario del Estado garante o regulador. principios tradicionales" (Ariño, 1970, pág. 98). Pero esa huida general del derecho que informa al Estado, significaba, simplemente, la adopción de un régimen jurídico-administrativo singular al albor de la creación del respectivo órgano autónomo, lo cual de ningún modo constituía una huida como tal del derecho público administrativo. No obstante, ocurrió en el derecho positivo español que esa exigencia de pretendida movilidad y eficacia terminó en un sometimiento casi total del derecho privado de dichas entidades, dando lugar, en consecuencia, a que la doctrina lo considerase una auténtica apostasía del derecho administrativo (Garrido, 1991, pág. 18).

Sin perjuicio de antecedentes más antiguos, ${ }^{6}$ se puede decir que la huida del derecho administrativo en España se inaugura con carácter general a partir de la reforma orgánica que introdujo la Ley General Presupuestaria (LGP) del 4 de enero de 1977, modificada, a su vez, por el Real Decreto Legislativo 1091 de 1988. En razón de estas reformas, se introduce en su artículo 6.1.b) una nueva categoría dentro de las sociedades estatales, esto es, las entidades de derecho público, que por ley sujetan su actividad al derecho comercial, civil y laboral. Del mismo modo, en el artículo 6.5 se crea un nuevo tipo de entes del sector público a los que se refiere como "el resto de los entes del sector público estatal no incluidos en este artículo ni en los anteriores", el cual dio lugar a la creación de entidades con régimen jurídico especial, que en general respondían al régimen jurídico privado.

6 Caso Red Nacional de Ferrocarriles Españoles (RENFE), creada por Ley de 24 de enero de 1941 y el Reglamento de Contratos del Estado aprobado por Decreto 3410 de 1975. 
Al amparo de lo anterior, tal como lo describe Martín-Retortillo (1996), se dio una recalificación jurídica de distintas entidades organizativas que operaban ya en los cuadros de la administración pública. Proceso escalonado que, como lo señalaba el mismo jurista español, se manifestaba en un triple sentido:

En primer lugar, cambio, fragmentación reiterada de la ordenación de la Administración del Estado mediante la creación de nuevos organismos autónomos, generalmente de carácter comercial, industrial, financiero o análogo. En segundo lugar, reconversión de organismos autónomos en sociedades estatales, de modo principal en las del supuesto del artículo 6A.b). Por último, creación de las nuevas entidades del artículo 6.5 o inclusión en ellas de sociedades estatales ya existentes (pág. 34).

Mención especial merece el caso de la Agencia Estatal de Administración Tributaria, muy llamativa para la doctrina del país ibérico. Esta Agencia, creada por el artículo 103 de la Ley 31 de 1990, de 27 de diciembre, ${ }^{7}$ de Presupuestos Generales del Estado para 1991, se constituyó de manera efectiva el 1 de enero de 1992, resultando ser la concreción de aquellos entes previstos en el artículo 6.5 de la LGP. En el ejercicio de las competencias de recaudación se rige por el derecho público; mas, para el resto de sus actividades se somete al derecho privado, vale decir, en materia de contratación, gestión de personal, laboral, régimen patrimonial, etc. De este modo, se trata de una entidad que, a pesar

7 Luego modificada, entre otras normas, por las leyes 18/1991 de 6 de junio; 14/1996 de 30 de diciembre; $65 / 1997$ de 30 de diciembre; $55 / 1999$ de 29 de diciembre y 14/2000 de 29 de diciembre. de desarrollar actividades que se han entendido como de la esencia del Estado, esto es, la recaudación de impuestos, su régimen jurídico se instrumenta, en gran parte, por el derecho común.

En suma, en virtud de la anterior normatividad, muchos organismos autónomos, que desarrollaban actuaciones materialmente administrativas, o que eran titulares de una situación de privilegio, monopolio o autoridad pública, se transformaron en sociedades estatales, sustrayéndose, de este modo, al sometimiento del derecho administrativo. En ese sentido, la denuncia de la doctrina administrativista en relación con dicho fenómeno es por razón de la realización de tareas administrativas a través de la utilización de la empresa pública, la cual supone, en atención a su forma jurídica, la disciplina del derecho privado.

La perplejidad, entonces, de la doctrina española en relación con la huida del derecho administrativo descansa no tanto en la aplicación del derecho privado a la administración pública, pues este subsistema jurídico no le ha sido totalmente ajeno, máxime si se trata de actividades de concurrencia económica, sino, antes bien, la expresión que este llegó a alcanzar, dado que impregnó a aquellas funciones que se han entendido como propias del Estado.

Pero así como se habla de la huida hacia el derecho privado, también se hace mención a la "vuelta del derecho público". Ello acontece, evidentemente, merced a la misma dinámica del derecho positivo español, como de la influencia de la normatividad comunitaria. Proceso que se 
inicia con la Ley de Contratos de las Administraciones Públicas del 18 de mayo de $1995,{ }^{8}$ la Ley de Organización y Funcionamiento de la Administración General del Estado del 14 de abril de 1997, ${ }^{9}$ y la Ley 48 de 30 de diciembre de 1998 por la cual se recogen las Directivas de la Comunidad Europea en materia de contratación. ${ }^{10}$ Normatividad anterior que, en su momento, si bien no estuvo exenta de críticas en cuanto a la advertencia de ciertas fórmulas de escape hacia el derecho privado (Ariño Ortiz, 2003, págs. 116-132), en todo caso, sí constituyó un esfuerzo por retomar los cauces del derecho público.

\section{Posiciones doctrinales en relación con la huida del derecho administrativo}

Como se acotó en la introducción del presente trabajo, es prolija la literatura sobre el tema objeto de estudio, dado que son muchos los juristas administrativistas que de algún modo $u$ otro se han ocupado del fenómeno de la huida. Sin embargo, no todos le otorgan el mismo alcance a dicho tópico. Mientras en un extremo encontramos posiciones que cuestionan la validez del uso del derecho privado por parte de la administración, en el otro extremo no hay reproche alguno, existiendo, en el entre tanto, posiciones in-

8 Posteriormente derogada por el Real Decreto Legislativo 2 de 2000, de 16 de junio, por el cual se aprueba el Texto Refundido de la Ley de Contratos de las Administraciones Públicas. Actualmente está en vigor el Real Decreto Legislativo 3/2011, de 14 de noviembre, por el que se aprueba el Texto Refundido de la Ley de Contratos del Sector Público.

9 Esta reforma supuso una nueva reorganización y racionalización de la administración institucional de España. Esta norma ha sido modificada parcialmente, entre otras, por las leyes 50/1998, 53/2002, 33/2006, $28 / 2006,15 / 2007$ y $22 / 2013$.

Directivas 90/531/CEE, 92/13/CEE y la 93/98/CEE. termedias sobre dichos extremos. ${ }^{11}$ Con todo, al margen de las posibles diferencias, "todas ellas ponen el acento en el control judicial -sea este civil o contencioso-administrativo- de la vinculación al derecho de la Administración pública cuando media una relación ad extra" (Descalzo González, 2011, pág. 49).

De esta manera están, en primer lugar, las posiciones de Parada Vásquez (1992), y Del Saz Cordero (1992) para quienes la administración no tiene libertad de elección de formas jurídicas, comoquiera que en el derecho del país ibérico existe una reserva constitucional de derecho administrativo, de suerte que el fenómeno de la huida no merece otra calificación que la de su inconstitucionalidad. Según ellos, la Constitución Española (cE) establece una verdadera "garantía institucional que la hace inmodificable por el legislador ordinario", puesto que el "sometimiento pleno de la ley y al derecho" de que trata el artículo 103 de la cE no se refiere a "cualquier derecho", sino cabalmente al derecho administrativo. Conclusión a la que llegan luego de una interpretación conjunta de esa y otras disposiciones contenidas en la Ley Fundamental.

Esta postura es compartida plenamente por Gaspar Ariño (2003), para quien la huida al derecho privado no es solo una huida del derecho administrativo, sino nada menos que una "huida del Derecho". Pues, en efecto, para dicho juris-

11 En este acápite no se pretende, desde luego, agotar toda la literatura que existe sobre el particular. Se desarrollarán, eso sí, las posiciones de aquellos autores que han sido más representativos sobre dicho tópico. 
ta, la CE se "refiere a unos principios connaturales a un régimen de derecho público que sólo el Derecho Administrativo puede garantizar" (pág. 111). La utilización del derecho privado supondría la puesta en peligro del Estado de derecho ya que dicho régimen, por su propia naturaleza, es incapaz de salvaguardar los principios que regenta la Constitución. Por tal virtud, el aludido autor propone que, si lo que se trata es de obtener una mayor agilidad en la administración, "no hay más remedio que reformular el Derecho Administrativo, aumentar su flexibilidad cuando sea necesario, pero manteniendo en todo caso garantías de objetividad y buena gestión que vinculen a los políticos" (Ariño, 2003, pág. 108).

En el otro lado se encuentra Barrojo Iniesta (1993), quien, por el contrario, defiende la suficiencia del derecho privado para la administración pública. Así, explica que la administración en este escenario no actúa como propietario sino como "administrador de intereses ajenos". Añade que en el derecho civil, mercantil y laboral se hallan ciertos controles que enervan el quehacer libre de la administración dado que en este régimen permean normas del ius cogens. Aunado a lo anterior, repara que en la Constitución y en el derecho comunitario se encuentran un haz de deberes para la administración, por lo que, en definitiva, la huida hacia el derecho privado no quiere decir, en modo alguno, "huida del derecho", incluso ni siquiera la "huida del derecho público" sino la "huida de las leyes administrativas". Por ello, a la postre, este fenómeno de huida conduce, a su juicio, a la elaboración jurisprudencial de un nuevo derecho común adecuado a las administraciones públicas, que les obligue a actuar sujetas a los principios constitucionales de igualdad, mérito y capacidad.

Por su parte, Martín-Retortillo (1996), si bien acepta que la huida hacia el derecho privado por parte de la administración comporta la reducción, cuando no la cancelación del conjunto de garantías que impone el Estado de derecho, que en última instancia no es más que el sistema de garantías de los ciudadanos, no comparte la posición extrema de la inconstitucionalidad por la marginación del derecho administrativo. Sin embargo, por razón del diseño actual del ordenamiento español, repara -este autor-que el régimen jurídico-administrativo es el único que puede ser capaz de garantizar los principios que prevé la Constitución para el actuar administrativo. Finalmente, propone, para efectos de acotar el fenómeno de la huida, la integralidad de la fiscalización de la jurisdicción contencioso-administrativa sobre la administración cualesquiera sean las fórmulas que revista, toda vez que detrás de ellas siempre habrá un poder público sujeto como tal a los principios constitucionales que encuentran su cauce a través del derecho administrativo.

Laguna del Paz (1995), a su vez, bajo la misma línea asevera que las formas y regímenes jurídico-privados no permiten garantizar los principios públicos necesarios en toda actuación de la administración, y que, de contera, aseguren la consecución de los intereses generales dentro del respeto a los derechos y legítimos intereses de los particulares. Por tal razón, manifiesta que, siendo el derecho administrativo el dere- 
cho propio de la administración, el recurso a las instituciones del derecho común debe ser solo una "solución excepcional", justificada en cada caso, lo cual supone, sin embargo, un "reforzamiento de los controles y responsabilidades".

Por otro lado, García de Enterría y Fernández (2006) recuerdan que al margen del régimen jurídico que adopten los entes convencionales, son administración pública, y, en tal virtud, poder público, sujetos, por lo tanto, a ciertos principios constitucionales de inexorable observancia. Se trata de un cuadro principialístico informado nada menos que por los de legalidad; interdicción de la arbitrariedad y responsabilidad (art. 9); objetividad e imparcialidad (art. 103); procedimiento debido y participación de los interesados (art. 105), control judicial de la legalidad y del fin de la actuación (art. 106), entre otros de la Constitución de 1978.

Añaden, igualmente, que el derecho administrativo, al ser el derecho estamental de la administración, se convierte en el salvoconducto o la llave de paso que habilita la instrumentación del derecho privado, ya que para su aplicación siempre habrá una decisión de carácter público, por lo que la "eventual utilización de formas privadas es, pues, un arbitrio puramente instrumental, práctico" (pág. 57).

Finalmente, para Parejo Alfonso, -citado por Descalzo González (2011, págs. 56-63)-, el tema relativo a la "potestad organizacional de la actuación administrativa" explica gran parte de la emergencia y manifestación de la huida del derecho administrativo, que cabalmente se pro- yecta en la "disociación entre forma de las organizaciones y régimen regulador de su funcionamiento y actividad". De esta suerte, el aludido jurista, partiendo del supuesto de que la "organización” resulta determinante en la manera de prestar la actividad, precisa que es menester entrever la particular construcción de la personalidad y construcción jurídica de la administración al interior de la vigente Constitución. Así las cosas, en razón de los artículos 97, 103 y 107 de la $\mathrm{CE}$, deduce que la administración cuenta únicamente con una capacidad jurídica de derecho público en tanto está al servicio del interés general; por tal virtud, concluye y coincide con otros autores en que no existe libertad de elección de las formas organizativas y de acción por parte del poder público.

Con todo, dicho jurista, tomando en consideración, por una parte, que la administración pública no es "una categoría compacta y homogénea, sino más bien un complejo sistema de piezas de lógica distinta", y por otra, la existencia de una unidad del ordenamiento jurídico, señala que es posible apelar a la rama jurídico-privada en el desarrollo del proceso ejecutivo administrativo cuando haya ausencia de prescripción constitucional prohibitiva y según los posibles esquemas de actividad y organización que la administración puede proyectar, ${ }^{12}$ entendiendo

12 Según lo explicado por Descalzo González, tres son los supuestos posibles donde entran en relación actividad y organización: "En primer lugar, el ámbito de las actividades definidas legalmente como públicas para la realización infraconstitucional de la función ejecutiva, con construcción y atribución de las correspondientes potestades-competencia. En segundo término, el de las actividades auxiliares de las propiamente administrativas, las logísticas y las de gestión de los propios bienes. Y, finalmente, el de las actividades con relevancia económica, esto es, que impliquen la entrada y permanencia en el mundo de la empresa" (2011, pág. 62). 
siempre, eso sí, que esta integración "no hace de la actividad administrativa, sin más, una actividad privada".

\section{DE LA HUIDA DEL DERECHO ADMINISTRATIVO EN COLOMBIA}

\section{A. Aspectos previos}

El nombre del presente título es sugestivo. Pareciere indicar, de su tenor literal, que Colombia padeciera, sin más, el mismo fenómeno de la huida objeto de estudio. En modo alguno se busca sugerir dicha idea. El propósito es otro. Se quiere, pues, entrever si la aludida situación ha tenido cabida dentro de nuestro régimen jurídico-administrativo, amén de las peculiaridades de nuestro propio ordenamiento jurídico y de la recepción que, a la par, ha proyectado en la doctrina administrativista colombiana.

Para tales efectos conviene retener lo que hasta el momento se ha trabajado. La peculiaridad que ofrece el derecho positivo español y que dio lugar a la denominada huida del derecho administrativo fue, ciertamente, la extensión que este llegó a alcanzar, vale decir, la instrumentación casi total de las técnicas y formas de derecho privado para aquellas actuaciones que suponían el ejercicio de auténticas funciones administrativas. La técnica que permitió esa válvula de escape fue la utilización de personas jurídicas instrumentales. Esta consistía en entroncar ciertas "formas organizacionales", generalmente sociedades mercantiles, para la realización de actividades relativas al ejercicio de autoridad, de privilegio, monopolio; en suma, funciones que se entienden como propias del Estado.

Por el contrario, para la mayor parte de la doctrina española, el recurso al derecho privado es perfectamente legítimo cuando la administración desarrolla actividades de "gestión económica"; categoría denominada por Villar Palasí (1950) a mitades del anterior siglo para describir aquellas funciones de la administración dirigidas a la producción y dación de bienes económicos materiales al mercado, en las que actúa como un agente más junto a los empresarios particulares, sin que su actuación sea normalmente exclusiva. Actividad esta que en cualquier caso no implica dispensar a una organización inequívocamente pública por su origen y financiación (empresa pública) de las vinculaciones que la Constitución de dicho país impone (García de Enterría y Fernández, 2006).

En atención a lo precedente, es necesario decantar, como se acotó, cuáles han sido las vicisitudes de esta estirpe que ha experimentado nuestro sistema jurídico.

\section{De la huida hacia el derecho privado en el ordenamiento jurídico colombiano. Alcances y consecuencias}

Sobre este tópico, se puede decir que el ordenamiento jurídico-administrativo colombiano no ha estado exento de remisiones al derecho privado, ya sea para disciplinar actividades estatales a cargo de la administración, ora para la configuración de ciertas fórmulas organizacionales. 
Con todo, el fenómeno de la huida del derecho administrativo no ha tenido en nuestro medio la misma profundidad o intensidad que la del país ibérico. La dinámica de la realidad jurídica de nuestra administración descentralizada presenta, en efecto, algunas diferencias. ${ }^{13}$ Las razones de tal conclusión son las siguientes:

\subsection{Simetría entre forma, régimen jurídico y contenido}

En relación con este tema se puede decir que, por regla general, en nuestro sistema jurídico existe coherencia entre las formas elegidas para desarrollar el contenido de sus actividades con el régimen jurídico que las gobierna.

La concreción de esta tesis encuentra apoyatura desde la misma reforma administrativa de 1968, la cual, como se sabe, constituyó un gran esfuerzo por sistematizar, racionalizar y reorganizar la estructura y el funcionamiento de la administración nacional que no existía antes. Uno de los grandes aciertos fue clasificar el variado cúmulo de expresiones institucionales existentes a tres categorías jurídicas a saber: establecimientos públicos, empresas industriales y comerciales del Estado y sociedades de economía mixta. La aludida clasificación tomó como criterio orientador, para efectos de la aplicabilidad entre el derecho público y el derecho privado, la

13 Debe advertirse que en el presente trabajo solo se aborda la realidad jurídica de las entidades descentralizadas. No se aborda el régimen jurídico de otras entidades estatales que pueden calificarse como órganos autónomos constitucionales, verbigracia, el Banco de la República o las universidades públicas. La razón de ello es que, como se pudo constatar en la introducción del presente escrito, se busca cotejar la huida del derecho administrativo a la luz de la administración institucional o indirecta, que fue la situación que dio pie a la materialización del fenómeno de la huida. naturaleza de las actividades que dichas entidades estaban llamadas a desarrollar.

De esta suerte, los artículos 5, 6 y 8 del Decreto 1050 de 1968 preveían claramente una concordancia entre la naturaleza de la actividad con su régimen legal y la manifestación institucional encargada de desplegarla. Así, los establecimientos públicos eran organismos a quienes se les confiaba la atención de funciones administrativas conforme a las reglas del derecho público; por su parte, las empresas industriales y comerciales del Estado como las sociedades de economía mixta eran organismos creados o autorizados por la ley, encargados de dinamizar actividades de naturaleza industrial y comercial, disciplinadas por el derecho privado. Estos criterios hallaban, sin perjuicio de algunos matices, plena concordancia en el régimen jurídico de sus actos y contratos contenido en el capítulo VI del Decreto 3130 de 1968.

Desde luego, la aludida normatividad permitía que este tipo de entidades, además de la actividad principal que se les confiaba, tuvieran asignadas otras que no ostentasen la calidad de funciones administrativas en relación con los establecimientos públicos, y que ejercieran funciones públicas o prestaran servicios públicos además de su actividad económica tratándose de las empresas industriales y comerciales del Estado y las sociedades de economía mixta; pero en uno u otro caso, la actividad no principal era de carácter excepcional y debía cumplir una clara función de complementariedad (Tafur, 1977). 
Esta misma coherencia se encontraba, por demás, en las modalidades organizativas comprendidas dentro de la categoría de las entidades descentralizadas indirectas reguladas por el Decreto 130 de $1976 .{ }^{14}$

La reforma administrativa de la Ley 489 de 1998, que reemplaza la efectuada en 1968, y que se expide con el fin de poner a tono los postulados constitucionales, también conservó en gran parte la misma lógica de los derogados decretos 1050 y 3130. De este modo, la simetría entre contenido de la actividad y régimen jurídico se encuentra en los establecimientos públicos, las empresas industriales y comerciales del Estado, las sociedades públicas, ${ }^{15}$ las sociedades de economía mixta, y las superintendencias y las unidades administrativas especiales con personería jurídica. ${ }^{16}$

Sociedades de capital público, asociaciones y fundaciones de participación mixta y asociaciones de entidades públicas.

15 Con la expedición de la Ley 489 se puede afirmar que las sociedades públicas pueden ser de dos clases: "a) Aquellas que siguen la normatividad de las empresas industriales y comerciales del Estado conforme al parágrafo $1^{\circ} \mathrm{del}$ artículo 38 de la ley"; y "b) Las asociaciones entre empresas industriales y comerciales del Estado exclusivamente o entre éstas y otros entes territoriales $u$ otras entidades descentralizadas que revistan la forma societaria, las cuales se sujetan a las normas de su acto de creación, el Código de Comercio y las especiales determinadas en el artículo 94 de esa ley" (Consejo de Estado, Sala de Consulta y Servicio Civil, Concepto 1537, 23 de noviembre de 2003, G. Aponte).

16 Las superintendencias ejercen, especialmente, funciones de inspección, control y vigilancia atribuidas por la ley o mediante delegación que haga el presidente de la República. Las unidades administrativas especiales, por su parte, se ha entendido que cumplen funciones para desarrollar o ejecutar programas propios de un ministerio o departamento administrativo. En uno y otro caso dichos organismos o entidades cumplen funciones administrativas. El artículo 82 de la Ley 489 de 998 prevé que estos órganos con personería jurídica se sujetarán al régimen jurídico contenido en la ley que las crea, y que en lo no previsto en ella, al de los establecimientos públicos, es decir, al derecho público.
Así entonces, se puede dilucidar, por lo menos como regla general, que las grandes reformas administrativas de nuestro ordenamiento jurídico han estado permeadas por la correlación actividad/régimen-jurídico/forma.

Es de añadir que la aplicación preponderante del derecho público o del derecho privado en los aludidos tipos de entidades descentralizadas responde, evidentemente, a unos presupuestos axiológicos específicos; en otros términos, a una justificación emanada de cierta lógica de Estado o por la misma realidad económica.

Así, pues, la lógica de Estado informa, por lo menos en relación con aquellos países tributarios del sistema continental de derecho administrativo, que el ejercicio de la función administrativa demanda el uso de privilegios y prerrogativas para la consecución del interés general, ${ }^{17}$ pero, a su vez, como contrapartida de lo anterior, de limitaciones y garantías a fin de salvaguardar los derechos e intereses legítimos de los administrados, propósitos estos que solo pueden lograrse por la vía del derecho público.

A su vez, la realidad económica indica que si el Estado desea participar de manera directa en el mercado en concurrencia con agentes privados, lo debe desarrollar en condiciones de igualdad, sin ningún tipo de privilegios y prerrogativas, ya

17 Se advierte en este punto, que no es unánime la doctrina al indicar que la función administrativa lleve ínsito el ejercicio de poderes y privilegios. Se anota, antes bien, que estos poderes deben estar precedidos de autorización legal expresa. Por tal razón, un sector de la doctrina adopta como nota distintiva del quehacer administrativo un sentido teleológico, que no es otro que el de velar por los intereses generales. Bajo esa línea de pensamiento se colige que los poderes y prerrogativas son apenas un mero factor contingente. 
que la idea es que el discurrir de la empresa pública en este ámbito no deforme la competencia. Luego, es claro entender, como lo señala Correa Henao (2008, pág. 189), que si la administración va incursionar en la actividad empresarial, esta deba inscribirse:

necesariamente en el mercado y en las exigencias que le son propias. En consecuencia, el régimen jurídico de dicha actividad tiene que ser necesariamente el del derecho privado o común y en esa medida la posición jurídica en la que se encuentra el Estado cuando actúa como empresa resulta equiparable en tanto asimilable a la del sujeto ordinario de la libertad empresarial.

\subsection{Dosificaciones de la Corte Constitucional. Asociación entre entidades públicas}

La asociación exclusiva entre entidades públicas como personas jurídicas sin ánimo de lucro, creadas para cooperar en el cumplimiento de funciones administrativas o de prestar conjuntamente servicios que se hallen a su cargo, estaba desarrollada ya por el Decreto-Ley 130 de 1976. Particularmente, el artículo 7 de dicho estatuto prescribía que a las personas jurídicas así estructuradas se les aplicaban "las normas previstas para los establecimientos públicos, sin perjuicio de las particularidades que contengan los actos de su creación". En tal sentido, el régimen jurídico de los actos, contratos y función pública laboral no era otro que el de derecho público, con las salvedades que se hayan realizado en el acto que las crea.
El artículo 95 de la Ley 489 de 1998 reproduce la aludida entidad descentralizada indirecta, sujetándola, a contrario sensu, a las normas del Código Civil y no al derecho público, "con el propósito de agilizar y flexibilizar su funcionamiento". ${ }^{18}$

La disposición en comento es, sin dubitación, -bajo el entendimiento de la disociación entre contenido y régimen jurídico-, un claro reflejo del fenómeno de la huida del derecho administrativo, por cuanto el ropaje jurídico-privado gobierna una entidad cuya actividad está dirigida a la ordenación de actividades administrativas.

Sin embargo, esta disposición ha sido dosificada por la Corte Constitucional bajo la égida de la constitucionalización de los principios que informan la función administrativa en las entidades descentralizadas. Así, en sentencia C-671 de 1999, con ponencia del magistrado Beltrán Sierra, la aludida Corporación expresó que el artículo 95 de la Ley 489

sólo podrá considerarse ajustada a las normas superiores cuando la asociación surgida se sujete al mismo régimen que, en consonancia con la naturaleza de las entidades participantes y el régimen propio de función administrativa o de servicio público a su cargo hubiere señalado la ley de creación o autorización de éstas.

Por tal virtud, concluye la Corte, en cuanto al régimen de las asociaciones públicas, que "el ejercicio de las prerrogativas y potestades públicas, los regímenes de los actos unilaterales, de

18 Gaceta del Congreso n. ${ }^{\circ} 72$ de 1998. 
la contratación, los controles y la responsabilidad serán las propios de las entidades estatales según lo dispuesto en las leyes especiales sobre dichas materias".

De este modo, se puede ver que también el ordenamiento jurídico colombiano, bajo la particular interpretación de las disposiciones de la norma superior que desarrolla el Tribunal Constitucional, ha sido fuente de coto para una eventual huida, sin más, hacia el derecho privado cuando se trate del quehacer administrativo, articulando su sujeción al derecho público (administrativo).

\subsection{Transformación constitucional de la naturaleza jurídica de los servicios públicos. Cambio de paradigma}

La Constitución Política de 1991, sin ser ajena a los cambios que se habían producido en el derecho comparado, dio lugar a la superación del clásico modelo de carácter monopólico y público del servicio público, implementando, de este modo, uno nuevo sobre los cauces de la libertad económica. Esta connotación se debe a que esta actividad prestacional sufrió un proceso de privatización y liberalización, ${ }^{19}$ de suerte que por

19 Adviértase el carácter polisémico de la expresión "privatizar". Así, se habla de privatización material o funcional, privatización formal y privatización institucional. Este último término corresponde a su sentido más estricto, consistente en el cambio o traspaso de la propiedad pública a propiedad privada de una empresa o un sector económico. En su sentido más amplio coincide con aquellos fenómenos que se identifican con la "liberalización" o "contractualización", esto es, la devolución por parte del Estado a los particulares de la gestión privada de algún servicio o sector de la economía ya sea "despublificando" el servicio ("liberalización") o manteniéndolo ("contractualización"). Se trata entonces de un término genérico. Para tales efectos puede verse, Ariño Ortiz, G. (2003). Principios de derecho público económico. Modelo de Estado, gestión pública, regulación económica. Bogotá, Colombia: Universidad Externado de Colombia. expresa e inequívoca habilitación constitucional tanto el Estado como los particulares pueden concurrir a la prestación de servicios públicos sin necesidad de un "título habilitante".

Es este cambio constitucional el que ha dado lugar a que se sostenga que los servicios públicos han sufrido una mutación en su naturaleza jurídica, pasando de ser una expresión del poder de imperio del Estado, como una faceta más de la función administrativa, a convertirse en una actividad económica inherente a su finalidad social dentro de un mercado en competencia, reservándose el Estado, en todo caso, como director de la economía, la atribución de su regulación y control (Sánchez, 2008).

Este entendimiento, por demás, se ha venido consolidando al albor de la jurisprudencia nacional, en donde se sostiene que la prestación de los servicios públicos no constituye una función pública administrativa, salvo cuando el operador del servicio actúa con poderes y prerrogativas públicas, esto es, con potestades inherentes al Estado. ${ }^{20}$

Partiendo de esta base, y sin perjuicio de posturas contrarias, ${ }^{21}$ se puede decir que la legisla-

20 En la jurisprudencia constitucional pueden verse las sentencias C-558/2001, J. Araújo; C-305/2004, M. Monroy; y C-037 de 2003, A. Tafur. Igualmente, en la jurisprudencia contenciosa-administrativa se pueden ver, entre otras, Consejo de Estado, Sala de lo Contencioso Administrativo, Sala Plena, Auto S-701 de 23 de septiembre de 1997, C. Betancur; Sección Tercera, sentencia 27673 de 17 de febrero de 2005, A. Hernández.

21 Es tradición en la doctrina administrativista señalar que el servicio público, junto con la actividad de policía y de fomento constituyen el tríptico clásico en virtud del cual se dinamiza la actividad administrativa. Partiendo de ello, se sostiene que el mercado no tiene la virtualidad de mutar la naturaleza del servicio público, pues él es un accidente que no interfiere en la esencia de las instituciones, y que, en tal sentido, no 
ción posterior a la reforma constitucional, en la que se han recalificado a ciertas entidades públicas, o se han adoptado nuevas tipologías de entidades descentralizadas para la prestación de ciertos servicios públicos bajo un régimen general de derecho privado, no constituyen, en sí, una huida del derecho administrativo, por cuanto no se presenta ninguna disociación, es decir, porque no son función administrativa.

Como primer ejemplo de ello se puede traer a colación las transformaciones que dispuso el gobierno nacional -dentro de la habilitación constitucional otorgada por el artículo 20 transitoriosobre ciertas entidades públicas con la finalidad de ponerlas a tono con la situación de concurrencia en que se hallaban con agentes privados en sectores determinados de la economía. En tal sentido, recalificó algunos establecimientos públicos (sujetos integralmente al derecho público) como empresas industriales y comerciales del Estado (sujetas, por regla general, al derecho privado) manteniendo en todo caso el objeto que venían desarrollando. Tal es el caso de

la Empresa Nacional de Telecomunicaciones TELECOM - (Decreto 2123 de 1992), el Instituto Colombiano de Energía Eléctrica -ICEL- (Decreto 2120 de 1992), la Corporación Eléctrica de la Costa Atlántica -Corelca- (Decreto 2124 de

existe óbice para que se pueda admitir que la función administrativa se pueda desenvolver en el mercado. Del mismo modo, se anota que los servicios públicos son una típica función administrativa dadas las finalidades públicas comprometidas con su actividad, de suerte que los cambios en su modelo de gestión en modo alguno mitigan la subjetividad de sus destinatarios y la configuración de verdaderos derechos frente a estos. Al respecto, puede verse: Marín Cortés, F. (2010). Los servicios semipúblicos domiciliarios. Bogotá: Ed. Temis; Montaña Plata, A. (2005). El concepto de servicio público en el derecho administrativo. Bogotá: Universidad Externado de Colombia.
1992) y el Fondo Financiero de Proyectos de Desarrollo -FonADE- (Tafur, 1999, pág. 427).

Por otro lado, se encuentra la situación de las empresas sociales del Estado, reguladas en el capítulo III de la Ley 100 de 1993, en la que se determinó que la prestación del servicio de salud en forma directa por la Nación o las entidades territoriales, se realizará principalmente mediante una figura empresarial denominada empresa social del Estado. Estas entidades conciertan disposiciones de derecho público y privado para regular aspectos puntuales de su organización y actividad. Como un ejemplo de remisión al derecho común, el artículo 195 de la Ley 100 prevé que en materia contractual se regirán por el derecho privado, "pero podrá[n] discrecionalmente utilizar las cláusulas exorbitantes previstas en el estatuto General de Contratación de la administración pública".

Del mismo modo, con la expedición de la Ley 142 de 1994, se tiene que las entidades y empresas públicas que prestan servicios públicos domiciliarios, vale decir, las empresas industriales y comerciales del Estado y las empresas de servicios públicos oficiales y mixtas, están sometidas a un régimen jurídico que, por lo general, son las propias del derecho privado. Así, de los artículos $30,31^{22}$ y 32 de la aludida ley se desprende que en lo que concierne a sus actos y contratos, se gobiernan por los cauces del derecho común.

Finalmente, se halla, amén de la Ley 1341 de 2009, el régimen jurídico de los proveedores de

22 Modificado por el artículo 3 de la Ley 689 de 2001. 
tecnologías de la información y las comunicaciones (operadores de servicios de tic), que si bien no adoptó una tipología especial para la prestación de dichos servicios, razón por la cual siguen el régimen ordinario de la descentralización, es decir, la Ley 489 de $1998,{ }^{23}$ en todo caso, en virtud del artículo 55 de la aludida norma, sus actos y contratos, incluidos los relativos a su régimen laboral, "cualquiera que sea su naturaleza, sin importar la composición de su capital, se regirán por las normas del derecho privado".

\subsection{La remisión al derecho privado no es absoluta}

Huelga subrayar, por otro lado, que las entidades descentralizadas previstas en nuestro ordenamiento jurídico sujetas a un régimen de derecho privado, ya sea para la regulación de aspectos relativos a su organización o actividad, no se sustraen, por ese solo hecho, de ciertos principios o reglas jurídicas de derecho público en general, y de derecho administrativo en particular. Por ello se puede expresar que la administración descentralizada es una especie de híbrido entre estos dos subsistemas jurídicos. Bajo ese orden de ideas se infiere que nuestro país no es tributario de una verdadera apostasía del derecho administrativo.

Para entender mejor esto, es menester precisar que las entidades descentralizadas, como entidades estatales, están gobernadas por el de-

23 Según el Consejo de Estado, los proveedores de redes y servicios de telecomunicaciones de carácter estatal podrán organizarse, atendiendo a la lectura del artículo 73 de la Ley 1341, en sociedades públicas, sociedades de economía mixta y en empresas industriales y comerciales del Estado (Sala de lo Contencioso Administrativo, Sección Tercera, Auto 38344, 6 de diciembre de 2010, E. Gil Botero). recho positivo tanto en sus aspectos ad intra, esto es, en su estructura interna, como en sus aspectos ad extra, vale decir, en sus relaciones con terceros. Tanto en uno como en otro caso el derecho público está presente. La diferencia radica en su extensión y en el grado de intensidad.

Así por ejemplo, en relación con las empresas industriales y comerciales del Estado, se encuentra que estas están vinculadas a los organismos principales de la administración para efectos del control administrativo según los artículos 50 y 105 de la Ley 489 de 1998; quienes prestan sus servicios son trabajadores oficiales y empleados públicos de conformidad con la Ley 3135 de 1968 y los decretos 1848 de 1969 y 1950 de 1973; les son aplicables los principios presupuestales contenidos en la Ley Orgánica del Presupuesto (decretos 111 y 115 de 1996); están sujetas al control fiscal de acuerdo con la Ley 42 de 1993 y el Decreto 267 de 2000; sus servidores públicos son sujetos disciplinables conforme a la Ley 734 de 2002, etc.

Por su parte, las sociedades públicas de que trata el artículo 38 de la Ley 489 de 1998 se someten al régimen previsto para las empresas industriales y comerciales del Estado. Lo mismo acontece con las sociedades de economía mixta en las que el Estado posea el $90 \%$ o más de su capital social, de acuerdo con los artículos 38 y 97 ibídem.

En relación con las empresas y sociedades filiales de que trata el artículo 94 de la Ley 489 de 1998, si bien se rigen por las reglas del derecho común, particularmente por las del Código de 
Comercio, dichas disposiciones se aplican "sin perjuicio de aspectos regulados con carácter especial por otras disposiciones constitucionales y legales" (CConst., C-691/2007, C. Vargas). Así, entre otros aspectos, las mentadas entidades, en cuanto a su régimen de contratación,

debe atenderse lo previsto en el artículo 2, numeral 1, literal a), de la Ley 80 de 1993, que cataloga a las empresas industriales y comerciales, a las entidades descentralizadas indirectas y demás personas jurídicas en las que exista participación pública mayoritaria, como entidades del Estado para efectos de la contratación administrativa (CConst., C-691/2007, C. Vargas).

Del mismo modo, estas organizaciones se encuentran sujetas al control administrativo a fin de asegurar la conformidad de su gestión con los planes, programas y políticas del sector administrativo dentro del cual actúen, tal como lo preceptúa el numeral 6 del artículo 94 y el artículo 109 de la Ley 489.

En tratándose de las empresas de servicios públicos domiciliarios (ESPD), como bien lo anota David Suárez (2010, págs. 232 y 233), se tiene que en estas se hallan presentes altas dosis de derecho administrativo, por lo que su régimen no deja de ser más que una mixtura. De esta suerte, por ejemplo, en su relación con los usuarios, dictan actos administrativos, adelantan procedimientos administrativos y agotan la vía gubernativa; ${ }^{24}$ celebran algunos contratos con las cláusulas exorbitantes de la Ley 80 de 1993;

24

Con la Ley 1437 de 2011, vía administrativa o actuación administrativa. en unos casos deben adelantar sus procesos de contratación a través de licitaciones públicas; los contratos de condiciones uniformes tienen naturaleza mixta; en algunos de los servicios públicos domiciliarios siguen existiendo típicos contratos de concesión; y en las EPSD oficiales y en las empresas industriales y comerciales del Estado que prestan este tipo de servicios su personal está clasificado como servidores públicos.

En cuanto tiene que ver con los proveedores de servicios de tecnologías de la información y las comunicaciones, partiendo del hecho que para prestar dichos servicios no se adoptó una tipología estatal especial, es de suyo entender que en los aspectos no previstos en la Ley 1341 de 2009, su régimen jurídico no será otro que el de la naturaleza jurídica de la entidad descentralizada que previamente se haya optado, ${ }^{25}$ por lo que los aludidos proveedores estarán impregnados por las dosis de derecho público administrativo que estas entidades tengan en su estructura ad intra.

La Ley 1341, igual que como acontece con la Ley 142 de 1994, adoptó un régimen mixto en materia de relaciones contractuales con sus usuarios, lo que quiere decir que el "régimen se declara contractual, pero el contrato es objeto de regulación detallada a cargo del Estado" (Atehortúa, 2012, pág. 179). Igualmente, los operadores de servicios de TIC adelantan procedimientos administrativos conforme a la Ley 1437 de 2011 y expiden actos administrativos,

25 El cual, como se vio, no es más que el de las sociedades públicas, empresas industriales y comerciales del Estado y sociedades de economía mixta. 
en atención a las peticiones y reclamaciones hechas por los usuarios, tal como se desprende de los artículos 53 y 54 de la Ley 1341.

Además, en materia contractual, es de precisar que las ESPD y los operadores de servicios de TIC, por virtud del artículo 13 de la Ley 1150 de 2007 , así cuenten con un régimen contractual excepcional al de la Ley 80 de 1993, aplicarán en desarrollo de su actividad contractual, acorde con su régimen legal especial, los principios de la función administrativa y de la gestión fiscal de que tratan los artículos 209 y 267 de la Constitución Política, y estarán sometidas al régimen de inhabilidades e incompatibilidades previsto legalmente para la contratación estatal.

Los mismos principios deben observar -en razón del artículo 93 de la Ley 1474 de 2011- las empresas industriales y comerciales del Estado, las sociedades de economía mixta en las que el Estado tenga participación superior al cincuenta por ciento (50\%), sus filiales y las sociedades entre entidades públicas con participación mayoritaria del Estado superior al cincuenta por ciento (50\%), cuando estas desarrollen actividades comerciales en competencia con el sector privado o público, nacional o internacional, o en mercados regulados, puesto que en tal caso se rigen por las disposiciones legales y reglamentarias aplicables a sus actividades económicas y comerciales. En su defecto, esto es, cuando no se encuentren en situación de competencia, deben utilizar el procedimiento de selección abreviada de menor cuantía para los contratos que tengan como objeto su actividad comercial e industrial, salvo para los contratos de obra pública, consul- toría, prestación de servicios, concesión, encargo fiduciario y fiducia pública, para los cuales se aplicará la modalidad que corresponda.

\subsection{Limitaciones constitucionales}

En la Carta Política de 1991 se encuentra todo un plexo de disposiciones relativas a las entidades descentralizadas que afectan diferentes aspectos de su organización y funcionamiento. Esta normatividad se caracteriza por contener un haz de principios, reglas, procedimientos y controles de derecho público en general, y administrativo en especial. La comprensión de la administración descentralizada dentro de la estructura orgánica y actividad general del Estado demanda que, desde el mismo texto fundamental, se haya adoptado una serie de normas que sujete de manera directa a todo ente descentralizado por el solo hecho de serlo, al margen de la naturaleza de la actividad que vaya a desarrollar en la práctica.

Así, en palabras de la Corte Constitucional:

es claro que la calificación que haga el legislador de una entidad o de categorías de entidades como entidades descentralizadas (en desarrollo de la atribución contenida en el artículo 210 de la Constitución, en armonía con los principios contenidos en el artículo 209 ibídem) per se comporta la sujeción directa a reglas constitucionales que aluden a aspectos diversos de la organización, funcionamiento y control de todos los organismos que ostenten dicha calidad de entidades descentralizadas (sentencia C-629/2003, A. Tafur).

De este modo, a manera de síntesis y a título enunciativo, se relacionan algunas de las dis- 
posiciones constitucionales a que se encuentra sujeta toda entidad descentralizada:

i) Son creadas o autorizadas a propósito de la facultad que tienen los cuerpos políticos de representación popular de determinar la estructura de la Administración (arts. 150.7, 300.7 y 313.6), por lo que su existencia requiere de previo agotamiento de procedimiento de derecho público; ${ }^{26}$ ii) están sujetas a control administrativo o de tutela (arts. 115, 208, 189.13, 305.5 y 315.3); ${ }^{27}$ iii) deben observar los principios de la función administrativa (arts. 209 y 210); iv) la administración y ejecución del erario está sometida a controles que garanticen la máxima transparencia por lo que su gestión está sujeta al control fiscal (arts. 267 a 274); v) están sujetas a las normas de la Contaduría General de la Nación (art. 354); vi) a las normas constitucionales que consagran inhabilidades e

26 La existencia de toda entidad descentralizada presupone una decisión política instrumentada a través del derecho. Empero, en relación con las entidades descentralizadas indirectas, es preciso decir que en la práctica estas encuentran distintas modalidades para su concreción. Como lo expone Atehortúa (2012), la misma "i) puede ser especial, mediante la expedición de una ley que autoriza la creación de una determinada empresa; ii) puede ser general, mediante una ley que reconoce que un determinado tipo de empresas pueden asociarse para la creación de otras empresas, tal como sucede con las empresas sometidas a la Ley 142 de 1994 que tienen una autorización especial derivada del artículo 18 de esta Ley; y iii) puede encontrarse en los propios estatutos" (pág. 110).

27 De conformidad con la Corte Constitucional, la descentralización por servicios "siempre ha tenido como presupuesto una relación que implica un poder de supervisión y orientación que se ejerce para la constatación de la armonía de las decisiones de los órganos de las entidades descentralizadas con las políticas generales adoptadas por el sector, y que es llevado a cabo por una autoridad sobre otra, o sobre una entidad, control que el constituyente avaló cuando acogió esta forma de organización administrativa" (sentencia C-727/2000, V. Naranjo). De igual manera, en la misma providencia sostuvo la Corporación que el artículo 108 Superior debe entenderse en un sentido amplio, vale decir, que los ministros y directores de departamento administrativo son también los jefes de las entidades adscritas y vinculadas a dichos organismos. incompatibilidades (arts. 180-3, 292 y 323); vii) en materia presupuestal quedan sujetas a las reglas de la Ley Orgánica del Presupuesto (art. 352); vi) están permeadas por los deberes de información y transparencia a efectos de control político (arts. 208 y 300.7); vii) y el personal que se vincula a su administración ostenta el carácter de servidores públicos (art. 123). ${ }^{28}$

En relación con las anteriores disposiciones, es menester precisar el caso de la sujeción de los entes descentralizados a los principios de la función administrativa, pues su observancia no significa, ciertamente, que dichos órganos deban regirse necesariamente por el derecho administrativo. Una interpretación así iría en contra de la libertad de configuración legislativa que pregona la propia Constitución, máxime cuando es el mismo texto fundamental el que prevé entidades encargadas de realizar actividades de carácter industrial y comercial. Con todo, en virtud del principio del efecto útil de las normas, se considera que el artículo $210^{29}$ Superior demanda una interpretación negativa y positiva. Desde la primera, la norma en mención guarda una correlación lógica con la prohi-

28 A esta conclusión ha llegado la Corte Constitucional con base en el criterio orgánico vertido en el artículo 123 Superior. Así, la misma Corporación en sentencias C-722/2007, C. Vargas y C-736/2007, M. Monroy, ha advertido que el término "servidor público" constituye una categoría genérica dentro de la cual caben diferentes especies, incluso, distintas de las que se hallan previstas en la Constitución. Una de ellas es el caso de los servidores públicos bajo las mismas condiciones jurídicolaborales de los particulares. A pesar de ello, dichos trabajadores no dejan de ser servidores públicos, y por tal virtud les son aplicables los artículos 126 y 127 de la Carta Política.

29 El inciso primero del artículo 210 de la Constitución expresa que "Las entidades del orden nacional descentralizadas por servicios sólo pueden ser creadas por ley o por autorización de ésta, con fundamento en los principios que orientan la actividad administrativa". [Cursivas añadidas]. 
bición, la cual debe estimarse implícita, esto es, que al legislador le está proscrito diseñar un régimen jurídico para los órganos descentralizados que imposibilite, riña o contraríe la vigencia de los principios de la función administrativa; y desde la segunda, al legislador le está permitido dosificar el grado de intensidad o expansión de los principios de la actividad administrativa en este tipo de entidades de acuerdo con la naturaleza de su actividad, pero en modo alguno anularlos.

El desafío en todo caso estará en garantizar la obligatoria observancia de los aludidos principios cuando se trate de entidades sujetas por regla general al derecho común, pues se advierte la dificultad de su implementación si no están aparejados de los procedimientos y mecanismos de control para su cumplimiento. De nada serviría, verbigracia, prescribir que una determinada empresa pública está en el deber de seleccionar objetivamente a sus contratistas si no se dispone de los procedimientos que permitan una selección pública, abierta, que faculte la libre concurrencia, y que sancione aquellos actos basados en la mera liberalidad.

Esta es una denuncia que, por demás, ha sido subrayada por la doctrina. Así por ejemplo, en España, Del Saz Cordero (1994) se preguntaba de qué manera los contratos privados de las sociedades públicas estaban obligados a observar los principios de publicidad y concurrencia si no se sigue para su adjudicación unos procedimientos reglados que el derecho privado no disciplina. De igual manera, en Colombia, David Suárez (2010) se formulaba el mismo interro- gante con relación al artículo 13 de la Ley 1150 de 2007, manifestando que

la absoluta generalidad de los principios de la función pública-administrativa y de la gestión fiscal, entendida en sentido amplio, dificulta la determinación de contenidos específicos que viabilicen su operatividad en la actividad contractual cotidiana de los entes no sometidos al estatuto general de la contratación estatal (pág. 221).

Bajo ese panorama y a falta de concreción legislativa, corresponderá a cada ente descentralizado encargarse de la adopción e interpretación de los principios de la función administrativa por vía de autodisciplina reglamentaria, esto es, por medio de sus manuales de contratación. Del mismo modo, jugará un papel esencial la jurisdicción contencioso-administrativa que, a través de sus decisiones judiciales, estandarice vía precedente, la observancia de dichos principios.

\section{Posturas doctrinales de la huida del derecho administrativo en Colombia}

Sobre este tópico se puede decir que la doctrina colombiana tiene posiciones divergentes. Hay quienes le restan trascendencia al fenómeno de la huida, mientras que hay otros para quienes el tema es una preocupación de primer orden.

Así, en un extremo, autores como Santofimio (2001, págs. 174-181), partiendo de la base de que el derecho es uno solo, interrelacionado y dinámico, se aparta del supuesto problema de la huida del derecho administrativo. Explica, de este modo, que la vigencia o no del derecho ad- 
ministrativo en determinados fenómenos administrativos es, ante todo, propio “de la dinámica natural de la ciencia jurídica, que en cuanto fenómeno dialéctico adquiere el movimiento y la transformación necesaria según las circunstancias" (pág. 178). De esta suerte, añade, que cualquiera que sea el camino adoptado por la administración, llámese derecho público o derecho privado, lo importante es el "respeto y acatamiento al principio de la legalidad como rector y determinador de la existencia de aquella, y el cumplimiento de las finalidades sociales del Estado en la búsqueda de la consolidación del Estado social y democrático de derecho" (pág. 178).

De igual manera, Montaña Plata, citado por Suárez (2010, pág. 101), manifiesta al respecto que el concepto de huida del derecho administrativo debe negarse; es una invención de los españoles, no del resto de Europa. De esta manera señala que el derecho es uno, y que es el legislador en cada momento quien determina qué régimen jurídico debe aplicarse a determinados servicios o actividades.

Esta postura, de hecho, es consecuente con sus publicaciones. Para este autor la función administrativa es el presupuesto del derecho administrativo, mas dicha consideración no comporta la procedencia de un régimen $100 \%$ administrativista, sino las dosis que el legislador considere necesarias (Montaña, 2010, pág. 152). Por ello es que, a pesar de considerar a los servicios públicos como una típica función administrativa, reprocha el hecho de que a partir de ciertas decisiones jurisprudenciales se haya "desconfigurado" el régimen común de los agentes económicos públicos de que trata la Ley 142 de 1994 (Montaña, 2009).

Por otro lado, Tafur Galvis (1999), luego de estudiar el fenómeno de la huida del derecho público en la legislación desarrollada a partir de la Constitución Política de 1991, concluye que el régimen de derecho privado es insuficiente para asegurar las finalidades esenciales del Estado y preservar el interés público, "cuya consecución parece indefectiblemente vinculada a la utilización de instrumentos propios del derecho público, administrativo en especial" (pág. 416). Añade que la sujeción al derecho común en la administración puede generar en ocasiones aunque este no haya sido el móvil- la evasión a controles y requisitos establecidos para asegurar la protección de la sociedad y del propio Estado. Finalmente, admite una mayor sujeción al derecho privado por parte del Estado en su condición de agente económico directo en concurrencia con los particulares, en aras de los principios de igualdad y libre concurrencia, sin perjuicio de que esa mayor sujeción “esté acompañada de una regulación social encaminada a garantizar no solo los derechos individuales sino el interés público en juego" (pág. 454), máxime cuando se trate de aquellas actividades calificadas como servicio público.

Del mismo modo, Marín Cortés (2008) analiza el proceso de la huida con sus ventajas y desventajas, y aborda entre otros puntos el tema relativo de la remisión de la contratación pública al derecho privado, desarrollando una férrea defensa de la autonomía del derecho administrativo y de su capacidad reguladora entre el 
Estado y los ciudadanos. Como críticas el autor concreta los problemas atinentes a la incapacidad del derecho privado de comprometerse con la protección de los principios de la función administrativa; la ausencia de compromiso en la defensa de los derechos fundamentales; y la puesta en peligro de la racionalidad del ejercicio del poder del Estado en virtud del carácter flexible del derecho común.

Por último, para David Suárez (2010), el fenómeno de la huida es un tema fundamental; de allí que se haya ocupado de este en los servicios públicos domiciliarios regulados en la Ley 142 de 1994. Para este autor, si bien es ineludible no aceptar la existencia de nuevas realidades como las concernientes a los escenarios económicos, competitivos y empresariales, que demandan instrumentos jurídicos más ágiles y flexibles, circunstancia esta que justifica la mitigación del derecho administrativo tradicional, no es menos cierto que ello no habilita, sin más, a que el ejercicio de funciones públicas-administrativas se sometan en un todo, y sin excepción alguna, a las normas del derecho privado. Es insoslayable que en algunas ocasiones -asevera el autor- lo que se busca con el fenómeno de la huida es eludir ciertos derechos, garantías, principios, trámites, procedimientos, controles y responsabilidades que son más exigentes y garantistas en el derecho administrativo que en el privado. Por ello una de sus conclusiones es que no es razonable que se acepte sin condicionamiento alguno la vigencia del derecho común, sino que, antes bien, debe buscarse un derecho administrativo moderno, que responda a las exigencias actuales, en vez de quedarse embalsa- mado en los conceptos, categorías, métodos y técnicas que sirvieron en su momento para su creación, justificación y consolidación.

\section{CONCLUSIONES}

1.- El fenómeno conocido como huida del derecho administrativo propiamente dicho, está vinculado con la instrumentación de las técnicas y formas del derecho privado a aquellas funciones consideradas como auténticamente administrativas. En tal sentido, el reproche se centra en la disociación entre actividad y régimen jurídico, que en el presente caso se traduce en la disociación entre función administrativa y derecho administrativo.

2.- Como corolario de lo anterior, no debe considerarse como receptoras de dicho fenómeno la adopción de formas jurídicas de derecho común por parte de la administración pública, o la aplicación del derecho privado a organismos institucionalmente definidos como entidades públicas, para desarrollar funciones relativas a la producción y dación de bienes al mercado en un régimen de competencia, ya que en tal caso se trata de la asunción de fines y tareas por parte del Estado que, de ordinario, son del resorte de los particulares.

3.- La denuncia de la doctrina española al respecto, consistía precisamente en que lo precedente no se configuraba con todo rigor, puesto que la adopción de formas de derecho privado, a través de su administración institucional, se dinamizaba no solo para la realización de actividades de gestión económica, sino para la 
ordenación de actividades administrativas. La fórmula de escape del derecho administrativo se materializaba entonces mediante la utilización de sociedades mercantiles o de empresas públicas para gestionar funciones propias del Estado, el cual, por virtud de su forma organizacional, arrastra de suyo al derecho común.

4.- $\mathrm{Si}$ bien en Colombia se puede advertir a partir de la Constitución de 1991, como política jurídica, la asunción progresiva del derecho privado a las administraciones públicas, no por ello se puede calificar a la aludida situación como una verdadera apostasía del derecho administrativo, tal como se describió en su momento para el caso español, toda vez que en nuestro ordenamiento jurídico no se puede entrever de manera extensa e intensa una disociación entre función administrativa y derecho administrativo. Lo anterior, debido a que nuestras principales reformas administrativas son, en general, simétricas entre contenido y forma jurídica; por las dosificaciones que, a su vez, ha desarrollado la Corte Constitucional; porque los servicios públicos, en razón de su nueva lógica de gestión, ya no son considerados - por lo menos vía legal y jurisprudencial- una función pública administrativa; y por último, en razón de las mismas limitaciones constitucionales, cuyo carácter de norma jurídica habilita su aplicación de manera directa a los entes descentralizados.

5.- Sobre las limitaciones constitucionales conviene subrayar que las disposiciones relativas a las entidades instrumentales, sin perjuicio de la libertad de configuración legislativa del Congreso de la República, proyectan una suerte de zona de certeza negativa para el legislador, pues es claro que a este órgano del Estado le está proscrito diseñar un régimen que burle los principios y reglas que informan al sector público descentralizado. Huelga decir: el principio de reserva competencial a favor de las corporaciones populares de representación política para su creación o autorización; el principio de unidad de dirección política como corolario del control de tutela; los principios de la función administrativa, gestión fiscal y presupuestal; y los deberes de información y transparencia a efectos del control político.

6.- En atención a lo precedente, se puede inferir que el régimen jurídico de las entidades descentralizadas será, a lo sumo, de carácter mixto, esto es, una especie de imbricación entre derecho público y derecho privado, con la intensidad y expansión que el legislador considere necesarias en su dinámica ad intra y ad extra. En tal virtud, no es atendible predicar, por lo menos en Colombia, en razón de las disposiciones constitucionales, una huida hacia el derecho común de carácter puro por parte de los órganos instrumentales, pues su régimen siempre estará presidido - parafraseando a García de Enterría y Fernández- por un núcleo o sustrato básico de derecho público.

7.- Pero así como nuestra realidad jurídica no parecer ser tributaria del fenómeno de la huida del derecho administrativo, lo mismo se puede advertir sobre la recepción de este tema en relación con nuestra doctrina administrativa. En comparación con lo que acontece en España, son pocos los trabajos que de manera íntegra ocupan la preocupación de juristas administra- 
tivistas colombianos. Las razones pueden ser varias, una de ellas, merced a la dinámica de nuestro sistema jurídico, que difiere en muchos aspectos de lo sucedido en el país ibérico; otra, su misma formación académica, a manera de visión personal del derecho en general, y del derecho administrativo en especial.

8.- Finalmente, a modo de reflexión, habrá que cuestionar qué tan válido será sostener, amén de una realidad cada vez más compleja y globalizada, la pretensión de monopolizar un solo régimen jurídico para una actividad del Estado tan indeterminada como la función administrativa. La práctica parece mostrar que los subsistemas jurídicos públicos y privados se tienden a difuminar cada vez más, no solo en razón de la constitucionalización y convencionalidad del derecho, sino porque la misma dialéctica de la interacción social así lo exige. De igual modo, el derecho administrativo de hoy, como consecuencia de la participación activa de la sociedad civil en la consecución material del interés general, tiende a solidificarse o adquirir mayor vigor en las actividades relativas a la regulación, control y vigilancia, que las de gestión propiamente, sirviéndose para ello de la interpretación económica del derecho y del derecho económico, régimen este del cual no se sabe con certeza de qué subsistema jurídico participa, esto es, si del derecho público o del privado.

\section{Referencias}

Ariño Ortiz, G. (1970). La administración institucional: origen y personalidad. Revista de Administración Pública, (63), 85-130.
Ariño Ortiz, G. (2003). Principios de derecho público económico. Modelo de Estado, gestión pública, regulación económica. Bogotá, CoIombia: Universidad Externado de Colombia.

Atehortúa Ríos, C. A. (2012). Servicios públicos domiciliarios y las tic en el contexto del precedente judicial. Medellín, Colombia: Biblioteca Jurídica Diké.

Barrojo, I. I. (1993). El intento de huir del derecho administrativo. Revista Española de Derecho Administrativo, (78), 233-249.

Bobbio, N. (1989). Estado, gobierno y sociedad: por una teoría general de la política. (J. F. Santillán, Trad.). Ciudad de México, México: Fondo de Cultura Económica.

Bobbio, N. (2010). Liberalismo y democracia. (J. F. Santillán, Trad.). Ciudad de México, México: Fondo de Cultura Económica.

Brewer-Carías, A. R. (2005). Derecho administrativo. (Vol. I). Bogotá, Colombia: Universidad Externado de Colombia.

Consejo de Estado. Sala de lo Contencioso Administrativo. Sala Plena. Auto S-701 (C. P.: Carlos Betancur Jaramillo; septiembre 23 de 1997).

Consejo de Estado. Sala de lo Contencioso Administrativo. Sección Tercera. Sentencia 27673 (C. P.: Alier Eduardo Hernández Enríquez; febrero 17 de 2005). 
Correa Henao, M. (2008). Libertad de empresa en el Estado Social de Derecho. Bogotá, CoIombia: Universidad Externado de Colombia.

Corte Constitucional. Sentencia C-671 de 1999

(M. P.: Alfredo Beltrán Sierra: septiembre 9 de 1999).

Corte Constitucional. Sentencia C-727 de 2000

(M. P.: Vladimiro Naranjo Mesa: junio 21 de 2000).

Corte Constitucional. Sentencia C-558 de 2001

(M. P.: Jaime Araújo Rentería: mayo 31 de 2001).

Corte Constitucional. Sentencia C-037 de 2003

(M. P.: Álvaro Tafur Galvis: enero 28 de 2003).

Corte Constitucional. Sentencia C-629 de 2003

(M. P.: Álvaro Tafur Galvis: julio 29 de 2003).

Corte Constitucional. Sentencia C-305 de 2004

(M. P.: Marco Gerardo Monroy Cabra: marzo 30 de 2004).

Corte Constitucional. Sentencia C-691 de 5 de septiembre de 2007 (M. P.: Clara Inés Vargas Hernández: septiembre 5 de 2007).

Del Saz Cordero, S. (1992). Desarrollo y crisis del derecho administrativo: su reserva constitucional. En C. Chinchilla, B. Lozano y S. del Saz, Nuevas perspectivas del derecho administrativo: tres estudios (págs. 139 y ss). Madrid, España: Editorial Civitas/Universidad Nacional de Educación a Distancia.
Del Saz Cordero, S. (1994). La huida del derecho administrativo: últimas manifestaciones. Aplausos y críticas. Revista de Administración Pública (133), 57-98.

Descalzo González, A. (2011). La noción de derecho administrativo en España: algunas cuestiones de reciente actualidad. Bogotá, Colombia: Universidad Externado de Colombia.

Entrena Cuesta, R. (1998). Curso de derecho administrativo. (Décima segunda ed.). Madrid, España: Tecnos.

Esteve Pardo, J. (2012). La extensión del derecho público. Una reacción necesaria. Revista de Administración Pública, (189), 11-40

Esteve Pardo, J. (2014). Perspectiva e impacto de la crisis desde la nueva correlación entre Estado y sociedad. Revista da Nueva Época, (1).

García de Enterría, E., y Fernández, T. R. (2006). Curso de derecho administrativo. Madrid, España: Editorial Civitas.

Garrido Falla, F. (1985). Tratado de Derecho Administrativo. (Novena ed., Vol. I). Madrid, España: Centro de Estudios de Derecho Administrativo.

Garrido Falla, F. (1991). Privatización y reprivatización. Revista de Administración Pública, (126), 7-26. 
Laguna del Paz, J. C. (1995). La renuncia de la administración al derecho administrativo. Revista de Administración Pública, (136), 201-229.

Marín Cortés, F. (2008). Público y privado. Estudios sobre las transformaciones del derecho, del Estado y de la empresa. Bogotá, Colombia: Temis.

Marín Cortés, F. (2010). Los servicios semipúblicos domiciliarios. Bogotá, Colombia: Temis.

Martín-Retortillo, S. (1996). Reflexiones sobre la huida del derecho administrativo. Revista de Administración Pública, (140), 25-44.

Medina López, D. (2007). El sueño weberiano: claves para la comprensión constitucional de la estructura administrativa del Estado colombiano. Revista de Derecho Público, (19), 1-42.

Montaña Plata, A. (2005). El concepto de servicio público en el derecho administrativo. Bogotá, Colombia: Universidad Externado de Colombia.

Montaña Plata, A. (2009). La desconfiguración del régimen jurídico de los servicios públicos domiciliarios a partir de la calificación de entidades públicas a las empresas de servicios públicos mixtas. Revista Digital de Derecho Administrativo, (3), 163-190.

Montaña Plata, A. (2010). Fundamentos de derecho administrativo. Bogotá, Colombia: Universidad Externado de Colombia.
Parada Vásquez, R. (1992). Derecho administrativo. Parte General. (Cuarta ed., Vol. I). Madrid, España: Marcial Pons.

Rivero, J. (2002). Páginas de derecho administrativo. (H. G. Duque, Trad.). Bogotá, Colombia: Universidad del Rosario.

Sánchez Luque, G. (2008). ¿Las empresas prestadoras de servicios públicos privadas son entidades estatales? Revista Contexto, (25), 57-100.

Santofimio Gamboa, J. O. (2001). Tratado de derecho administrativo. (Tercera ed., Vol. I). Bogotá, Colombia: Universidad Externado de Colombia.

Suárez Tamayo, D. (2010). Huida o vigencia del derecho administrativo: el caso de los servicios públicos domiciliarios. Transformarciones - Tendencias del derecho administrativo. Medellín, Colombia: Librería Jurídica Sánchez.

Tafur Galvis, Á. (1999). La huida de la administración hacia el derecho privado en colombia. En Derecho civil y comercial -doctrina- (págs. 411-456). Medellín, Colombia: Bliblioteca Jurídica Diké.

Tafur Galvis, Á. (1977). Las entidades descentralizadas. Bogotá, Colombia: Temis.

Villar Palasí, J. L. (1950). La actividad industrial del Estado en el Derecho Administrativo. Revista de Administración Pública, (3), 53-129. 